ENVIRONMENTAL RESTORATION PROGRAM

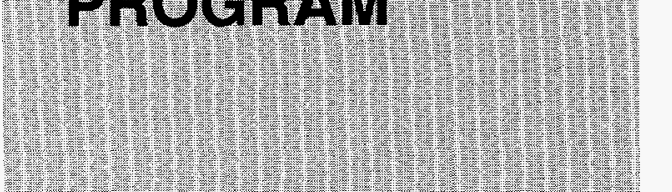

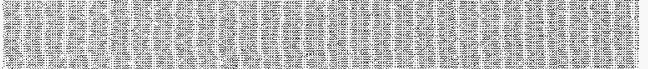
Mrat

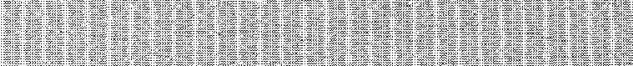
1) 10.

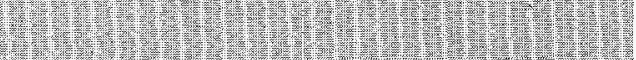

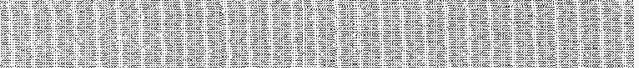

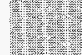
MU) 4: 7.

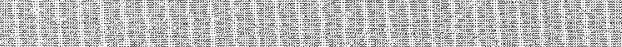
1).$$
\text { tes }
$$$$
\text { 1.:- (m) }
$$ 


\section{DISCLAIMER}

This report was prepared as an account of work sponsored by an agency of the United States Government. Neither the United States Government nor any agency thereof, nor any of their employees, make any warranty, express or implied, or assumes any legal liability or responsibility for the accuracy, completeness, or usefulness of any information, apparatus, product, or process disclosed, or represents that its use would not infringe privately owned rights. Reference herein to any speciffc commercial product, process, or service by trade name, trademark, manufacturer, or otherwise does not necessarily constitute or imply its endorsement, recommendation, or favoring by the United States Government or any agency thereof. The views and opinions of authors expressed herein do not necessar. ily state or reflect those of the United States Government or any agency thereof. 


\section{DISClammer}

Portions of this document may be illegible in electronic image products. Images are produced from the best available original document. 
Energy Systems Environmental Restoration Program

\title{
Findings of the Wetland Survey of the David Witherspoon, Inc., 1630 Site, South Knoxville, Knox County, Tennessee
}

\author{
B. A. Rosensteel
}

Date Issued-March 1997

\author{
Prepared by \\ JAYCOR Environmental \\ Oak Ridge, Tennessee 37831 \\ under subcontract 28B-99230C \\ Prepared for the \\ U.S. Department of Energy \\ Office of Environmental Management \\ under budget and reporting code EW 20 \\ Environmental Management Activities at the \\ OAK RIDGE NATIONAL LABORATORY \\ Oak Ridge, Tennessee 37831 \\ managed by \\ LOCKHEED MARTIN ENERGY SYSTEMS, INC. \\ for the \\ U.S. DEPARTMENT OF ENERGY \\ under contract DE-AC05-84OR21400
}

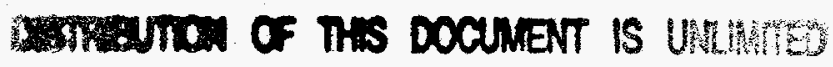

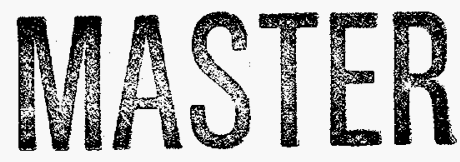




\section{CONTENTS}

EXECUTIVE SUMMARY $\ldots \ldots \ldots \ldots \ldots \ldots \ldots \ldots \ldots \ldots \ldots \ldots \ldots \ldots \ldots \ldots \ldots$

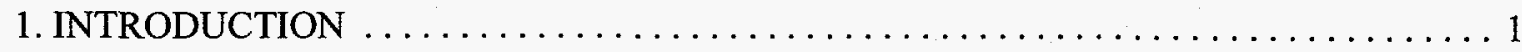

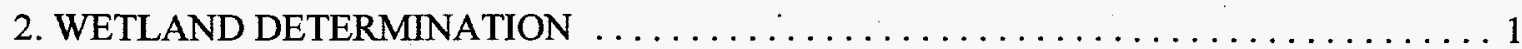

2.1 U.S. ARMY CORPS OF ENGINEERS METHODOLOGY $\ldots \ldots \ldots \ldots \ldots \ldots \ldots$.

2.2 ATYPICAL SITUATION WETLANDS $\ldots \ldots \ldots \ldots \ldots \ldots \ldots \ldots \ldots \ldots \ldots \ldots \ldots \ldots \ldots \ldots$

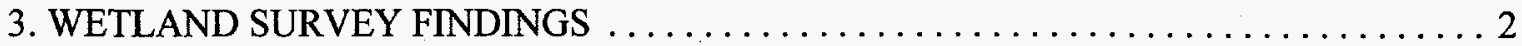

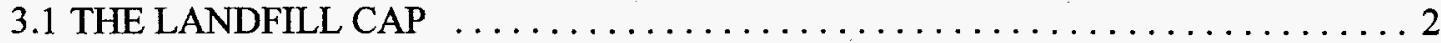

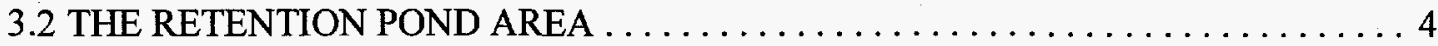

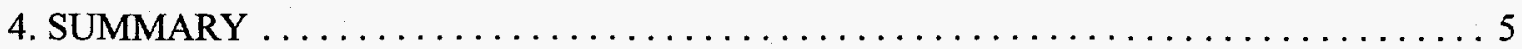

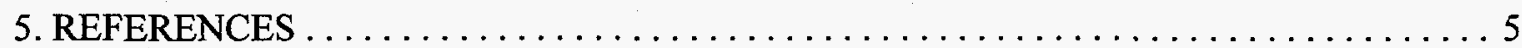

Appendix. WETLAND DETERMINATION DATA FORMS $\ldots \ldots \ldots \ldots \ldots \ldots \ldots$ A-1

\section{FIGURES}

1 Aerial Photo of David Witherspoon, Inc., Site 1630 Wetlands . . . . . . . . . 3 


\section{EXECUTIVE SUMMARY}

Executive Order 11990, Protection of Wetlands, (May 24, 1977) requires that federal agencies avoid, to the extent possible, adverse impacts associated with the destruction and modification of wetlands, and that they avoid direct and indirect support of wetlands development when there is a practicable alternative. In accordance with Department of Energy (DOE) Regulations for Compliance with Floodplains and Wetlands Environmental Review Requirements (Subpart B, 10 CFR 1022.11), surveys for wetland presence or absence were conducted in September 1996 on the DWI-1630 site (Witherspoon Landfill) located in South Knoxville, Knox County, Tennessee. As required by the Energy and Water Development Appropriations Act of 1992, wetlands were identified using the criteria and methods set forth in the Wetlands Delineation Manual (Army Corps of Engineers, 1987). The wetlands identified in this survey were classified according to the system developed by Cowardin et al. (1979) for wetland and deepwater habitats of the United States.

The DWI-1630 site includes a closed, capped landfill area, areas of past disturbance adjacent to the capped area, and patches of hardwood forest. Wetlands were identified on the landfill cap and in a small bottomland that was formerly used for a retention pond in the southwest corner of the

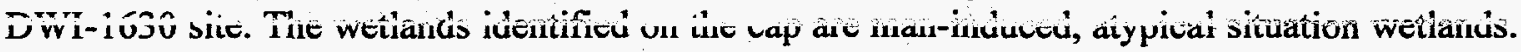
These areas have hydrophytic vegetation and wetland hydrology, but the soils do not have hydric characteristics. Wetland development appears to be due to a combination of the grading or subsidence of the clay landfill cap, the low permeability of the clay fill soil, and the absence of surface drainage outlets from the depressions. These atypical situation wetland areas may not be be considered by the U.S. Army Corps of Engineers or the State of Tennessee to be jurisdictional wetlands. The wetland in the former retention pond area has hydrophytic vegetation, wetland hydrology, and hydric soils and is a jurisdictional wetland. 


\section{INTRODUCTION}

A wetland survey was conducted on September 19, 1996 on the DWI-1630 site (D. Witherspoon Landfill) in South Knoxville, Knox County, Tennessee by JAYCOR Environmental assisted by staff of Jacobs Engineering. The DWI-1630 site includes the capped landfill area and adjacent areas of past disturbance, and patches of hardwood forest. The landfill was capped with clay soil in 1972. The capped area has stored on it many pieces of scrap metal, machinery, and equipment. The primary vegetation community on the cap and adjacent disturbed areas include many early successional plant species, such as lespedeza (Lespedeza cuneata), blackberry (Rubus sp.), and members of the Asteraceae family (i.e., goldenrods, asters), that readily colonize disturbed sites and old fields. There are numerous shallow topographic depressions on the capped area. These depressions were probably made during initial grading of the cap or subsequent landfill subsidence.

The areas surrounding the capped landfill include relatively undisturbed, second-growth oak forest on upland slopes to the east, west, and north; second-growth mesic forest on the slopes on the south end of the site; and disturbed, old-field areas adjacent to the capped area. These upland old field areas are dominated by red cedar (Juniperus virginiana), pines (Pinus sp.), hardwood saplings, Japanese honeysuckle (Lonicera japonica), and numerous herbaceous species common in old-field situations. Scrap metal and equipment are also stored in these areas.

Most of the site drains to the south into a small drainage that had been used as a runoff retention pond in the past. The area appears not to have functioned as a retention pond for some years because most of the drainage bottom and the adjacent uplands are vegetated with trees, shrubs, and herbaceous species.

\section{WETLAND DETERMINATION}

\subsection{U.S. ARMY CORPS OF ENGINEERS METHODOLOGY}

The wetland determination was performed using the U.S. Army Corps of Engineers methodology (USACE 1987). According to this methodology three parameters - hydrophytic vegetation, hydric soils, and wetland hydrology-must be present for an area to be identified as a wetland. With the exception of certain atypical or problem situations, an area must possess all of the following attributes to be positively identified as a wetland:

1. The vegetation community must be dominated by species classified as Obligate Wetland (OBL; estimated probability of occuring in a wetland is $>99 \%$ ), Facultative Wetland (FACW; usually occur in wetlands, but occasionally found in nonwetlands), and/or Facultative (FAC; equally likely to occur in wetlands or nonwetlands) (Reed 1988);

2. The soil must be hydric. Several indicators, including soil color and presence of mottles, can be used to determine if a soil is hydric. 
3. There must be evidence of wetland hydrology. All hydrologic characteristics of areas that are periodically inundated or have soils saturated to the surface at some time during the growing season. Evidence includes direct observations of inundation or soil saturation and indirect observations such as flood drift lines and silted leaf litter.

\subsection{ATYPICAL SITUATION WETLANDS}

The USACE (1987) addresses atypical situations in which one or more positive indicators of wetland presence may be absent in a wetland and describes procedures for determining if the area in question is a wetland. Atypical situations are those in which positive indicators of either hydrophytic vegetation, hydric soils, or wetland hydrology are absent because of effects of recent human activities or natural events. Atypical situations include areas in which there are unauthorized discharges requiring enforcement actions; natural events such as changing river courses, beaver dams, mudslides, and earthquakes; and human-induced wetlands that have been purposely or incidentally created by human activities.

\section{WETLAND SURVEY FINDINGS}

Wetlands were identified in two areas on the DWI-1630 site. These areas are the landfill cap and the former retention pond area (Fig. 1). Routine wetland determination data sheets (USACE 1987) were filled out for each of the wetland sites (Appendix).

\subsection{THE LANDFILL CAP}

There are numerous areas on the cap in which initial site grading or subsequent subsidence has formed depressions ranging in size from a few square meters to roughly 250-300 square meters. Wetlands have developed in four of these depressions (CAP-1 through CAP-4; Appendix). These wetlands are man-induced atypical situation wetlands. Two of the three necessary parameters - hydrophytic vegetation and wetland hydrology - were present, but the soils were not hydric. The wetlands have formed as a direct result of the grading or subsidence of the clay landfill cap, the low permeability of the clay fill soil, and the absence of surface drainage outlets from the depressions. The USACE may not consider these man-induced, atypical situation wetlands to be jurisdictional due to their location and development on a landfill cap and their isolation from ground water and surface waters.

The cap consists of low-permeability clay soils that were imported to the site. Because of the low permeability of the clay cap and the absence of surface outlets, precipitation and runoff are retained in the depressions. One to several inches of standing water was observed throughout or in portions of the depressions. Hydrologic data were not available for these areas, however, it is likely that water is retained in these depressions for extended periods during the year, including during the growing season. 


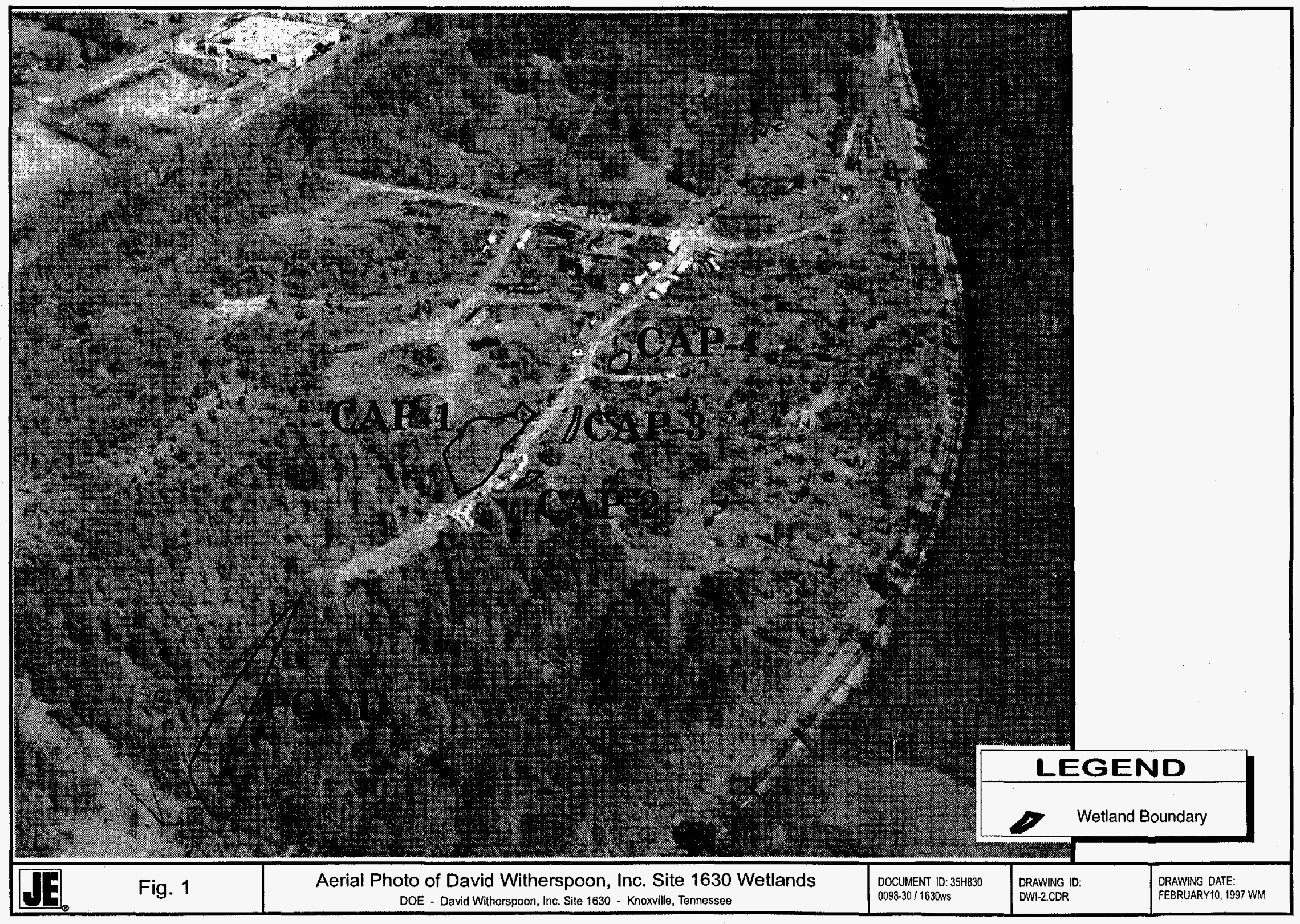

Fig. 1. Aerial photo of David Witherspoon, Inc., Site 1630 Wetlands. 
The presence of water for extended periods during the growing season has encouraged the growth of wetland vegetation. The depressions are dominated by hydrophytic vegetation, including woolgrass (Scirpus cyperinus; OBL), soft rush (Juncus effusus; FACW+), tickseed sunflower (Bidens polylepis; FACW), cattail (Typha latifolia; OBL), spikerush (Eleocharis sp.; OBL), fox sedge (Carex vulpinodea; OBL), Frank's sedge (Carex frankii; OBL), other sedges (Carex sp.), and saplings of black willow (Salix nigra; OBL) and sycamore (Platanus occidentalis; FACW-). These species are all early colonizers of wetlands that form in disturbed or recently cleared areas.

Although the surface soil in the depressions may be saturated for extended periods, characteristics of the clay soil, such as low organic matter content and low permeability, have inhibited the development of hydric characteristics. The matrix colors of the soils in the depressions included yellowish-brown (10YR5/6), dark red (2.5YR5/8), yellowish-red (5YR5/8), brown (10YR5/3), and dark grayish brown (10YR4/2). These high-chroma color clay soils (with the exception of the 10YR4/2, which contained a larger amount of partially degraded plant material) could require decades or more to acquire, through oxidation and reduction processes, the low-chroma colors and mottling of a hydric soil.

\subsection{THE RETENTION POND AREA}

At the foot of the landfill cap on the southwest end of the site is a small drainage that had been used in the past as a retention pond for site runoff. There is a low, earthen berm across the bottomland near the site boundary which detains water in the bottomland. The water drains from the site through a pipe at the pond outlet. The berm and the constricted outlet slows drainage of runoff from the bottomland, which is shallowly flooded during periods of high rainfall.

A wetland extends from the base of the fill to the berm within the level bottom area. At the base of the fill there is a small area dominated by trees and saplings. The midsection of the drainage is dominated by herbaceous species with scattered shrubs and saplings. The lower end of the wetland has sparse groundcover and is shaded by trees that grow on the edge of the bottom. Two locations were characterized for the wetland determination (POND 1 and POND 2; Appendix).

The dominant species include box elder (Acer negundo; FACW), black willow, green ash (Fraxinus pennsylvanica; FACW), and sycamore in the canopy and sapling strata, and false nettle (Boehmeria cylindrica; FACW+), cutgrass (Leersia sp.; OBL or FACW depending on species), and rough cocklebur (Xanthium strumarium; FAC). The soil is a gray (7.5YR5/1 and 10YR5/1) silty clay with mottles and manganese concretions. The soil was saturated to the surface and free water in the soil boring occurred at approximately 5 inches. The primary hydrologic source appears to be groundwater, however, surface runoff may also be an important contributor at certain times of year. 


\section{SUMMARY}

A wetland survey of the DWI-1630 site in Knox County, Tennessee, was conducted on September 19, 1996, using the USACE wetland delineation methodology. Four man-induced, atypical situation, isolated wetlands, ranging in size from approximately $72 \mathrm{~m}^{2}$ to $270 \mathrm{~m}^{2}$ were identified on the clay cap of the landfill. These wetlands have hydrophytic vegetation and wetland hydrology, but lack hydric soils. These wetlands may not be considered jurisdictional by the USACE or the State of Tennessee because of their location and development on a landfill cap and their lack of a surface drainage outlet. A jurisdictional wetland was identified in a drainage bottom, formerly used as a retention pond area, in the southwest portion of the site. This wetland, which has

groundwater as it's primary hydrologic source, has hydrophytic vegetation, hydric soil, and wetland hydrology.

\section{REFERENCES}

Reed, P.B. 1988. National List of Plant Species that Occur in Wetlands: Tennessee. USFWS Biological Report NERC-88/18.42.

U.S. Army Corps of Engineers. 1987. Wetlands Delineation Manual. Technical Report Y-87-1. Waterways Experiment Station, Vicksburg, MS. 
Appendix.

WETLAND DETERMINATION DATA FORMS 


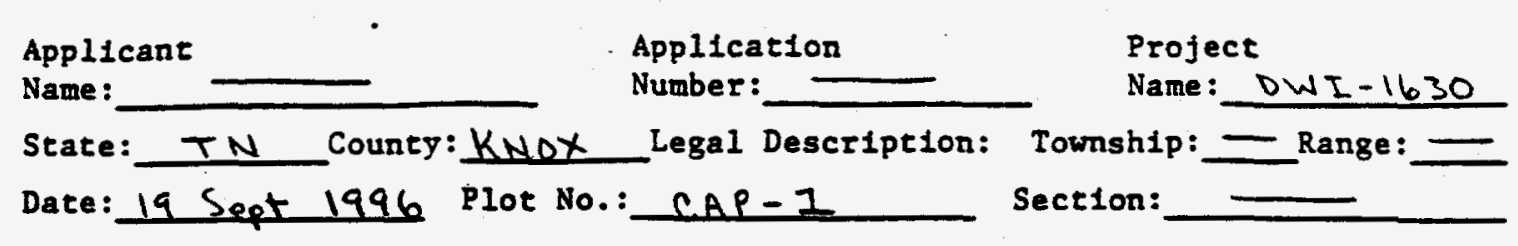

Vegetation [1ist the threc dominant species in each vegetation layer (5 if only 1 or 2 layers)]. Indicate specles with observed morphological or known physiological adaptations with an asterisk.

\begin{tabular}{|c|c|c|c|}
\hline Specles & $\begin{array}{l}\text { Ind1cator } \\
\text { Status }\end{array}$ & Species & $\begin{array}{l}\text { Indicator } \\
\text { Status }\end{array}$ \\
\hline
\end{tabular}

\section{Trees}

1.

2. NONE

3.

Saplings/shrubs

4. Salix nigra

5. Platamus occidentalis FACW-

6.

7 of species that are OBL, FACW, and/or FAC: 100 . Other indicators:
Herbs

$$
\text { 7. Scirpus eyperinus OBL }
$$$$
\text { 8. Typha latifolia ors }
$$$$
\text { 9. Juncus effusus facuit }
$$

Woody vines

10.

11. NONE

12. Hydrophytic vegetation: Yes $x$ No - Basis: Dommanace of OBL and FACW speciej

So11

Series and phase: Fill clay soil On hydric soils 1ist? Yes____ No $X$ Mottled: Yes $>6^{\prime \prime}$; No_. Mottle color: 2.5 YR6/3; Matrix color: 10 YR $5 / 6$ and loyr $5 / 8$ Gleyed: Yes__ No $X$ Other Indicators:

Hydric soils: Yes___. No $X$; Basis: Matrix color and fill clay

\section{Bydrology}

Inundated: Yes $X$; No - Depth of standing water: Saturated so11s: Yes $X$; No - Depth to saturated so11: at surface. Other Indicators: Wetland hydrology: Yes $x$; No - Basis: Panded water; surface saturation Atypical situation: Yes $X$; No Normal Circumstances? Yes No $x$. Werland Determinarion: Wetland $x$ ; Nonwetland Commencs: Man-induced Atypical Situation: Isolated depressions formed by capping a land-filled valley with clay soils. See Data Form 3 Approx. size: $250 \mathrm{~m}^{2}$ (0.025 ha) Determined by: B. ROSENSTEEL 
DATA FORM 1

WETLAND DETERMINATION

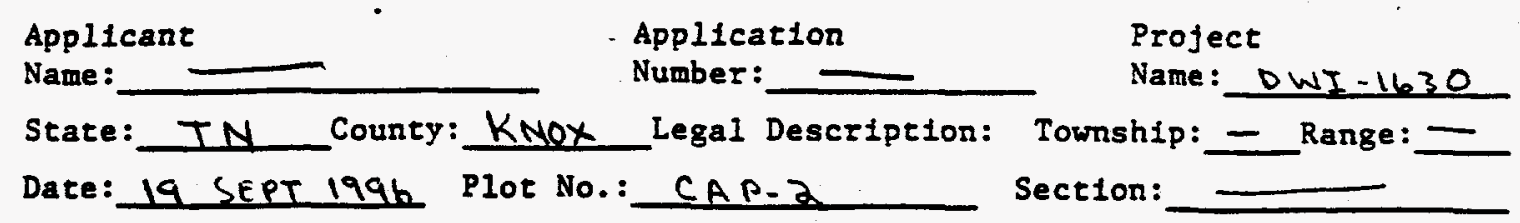

Vegetation (11st the threc dominant species in each vegetation layer ( 5 if only 1 or 2 layers)]. Indicate specles with observed morphological or known physiologteal adaptations with an asterisk.

\begin{tabular}{|c|c|c|c|}
\hline Species & $\begin{array}{l}\text { Indicator } \\
\text { Status }\end{array}$ & Species & $\begin{array}{c}\text { Indicator } \\
\text { Status } \\
\end{array}$ \\
\hline Trees & & Herbs & \\
\hline$\overline{1 .}$ & & 7. Typha latifolia & \\
\hline 2. NONE & & 8. Eleocharis sp- & $O B L$ \\
\hline $\begin{array}{l}3 . \\
\text { Saplings/shrubs }\end{array}$ & & $\begin{array}{l}\text { 9. Juncus effusus } \\
\text { Biaens polylepis } \\
\text { Woody vines }\end{array}$ & $\begin{array}{l}\text { FACWH } \\
\text { FACIN }\end{array}$ \\
\hline 4. Salix nigra & $O B L$ & 10. & \\
\hline 5. & & 11. & \\
\hline 6. & & 12. & \\
\hline
\end{tabular}

Sol1

Serles and phase: Clay fill soil on hydric solls 11st? Yes___ No $X$ _. Mottled: Yes_; No $X$. Mottle color:_____ Matrix color: $2.5 Y, Y / 8$ Gleyed: Yes__ No $X$ Other Indicators:

Hydric so11s: Yes___. No $X$; Basis: Lack of indicators; Fillsoil_.

Hydrology

Inundated: Yes___ No $X$ _. Depth of standing water:

Saturated so1ls: Yes $X$; No ___ Depth to saturated so11: At surface_.

Other 1ndicators: Interspersion of unvegetaled with vegetated substrate indicated recent Wetland hydrology: Yes__; No___. Basis:_____ ponding Atypical situation: Yes $X$; No Normal Circumstances? Yes__ No $X$. Wetland Determination: Wetland___ ; Nonwetland Comments: Man-induced Atypical Situation; Isolated depressions in clay landfill cap.

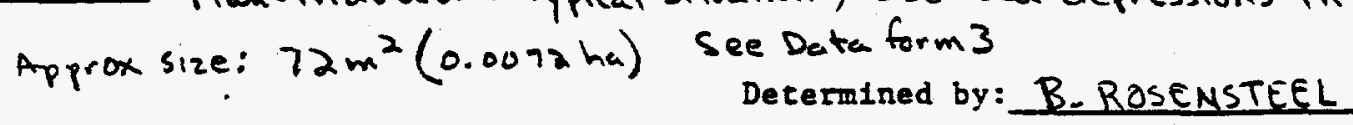
JAYCOR ENVIRONIMENTAL 
DATA FORM 1

WETLAND DETERMINATION

\begin{tabular}{|c|c|c|c|}
\hline $\begin{array}{l}\text { Applicant } \\
\text { Name: }\end{array}$ & & $\begin{array}{l}\text { Application } \\
\text { Number: }\end{array}$ & $\begin{array}{l}\text { Project } \\
\text { Name: DWI-1630 }\end{array}$ \\
\hline State: $T N$ & Councy: KNOX & _Legal Description: & Township: = Range: - \\
\hline
\end{tabular}

Vegetation [11st the threc dominant species in each vegetation layer (5 if only 1 or 2 layers)]. Indicate species with observed morphological or known physiological adaptations with an asterisk.

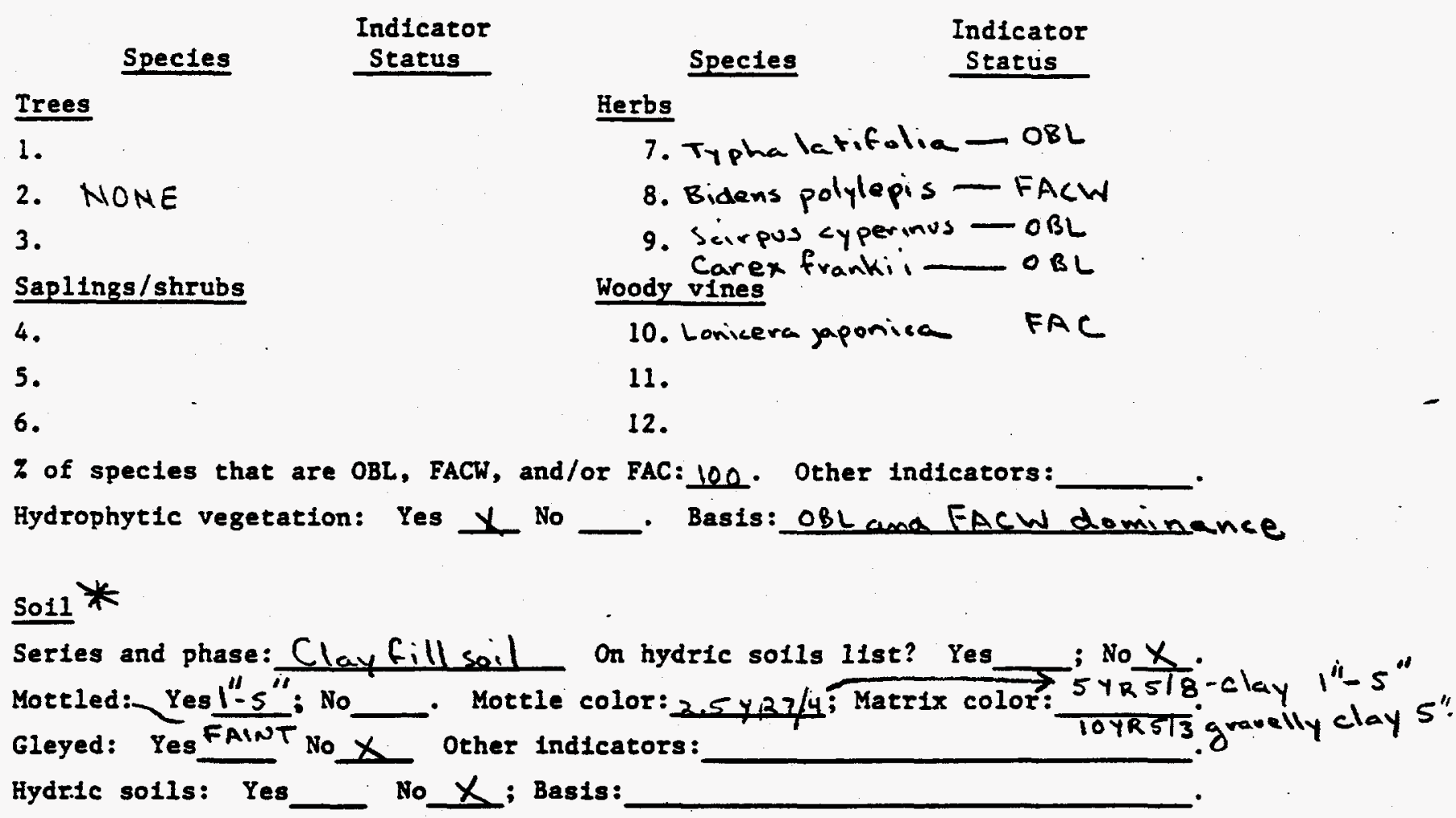

\section{Hydrology}

Inundated: Yes $X$; No___. Depth of standing water: $3^{\prime \prime}+$ in part of area.

Saturated so11s: Yes $X$; No ___. Depth to saturated so11: At surface throughout area Other Indicators: Interspersion of unvegetabd and vegetaled substrate indicated recen Wetland hydrology: Yes $X$; No - Basis: flooding Atypical situation: Yes $X$; No Normal Clrcumstances? Yes Wetland Determination: Wetland No $\frac{x}{x}$. ; Nonwetland

Comments: Man-ind veed Atypical Situation; I solated depression in clay landfill cap Approx. size: $270 \mathrm{~m}^{2}(0.027 \mathrm{ha})$. See Data form 3

* A second soil boring had a layer JAYCOR ENYIRONMIENTAL of foundry sand 


\begin{tabular}{|c|c|c|c|}
\hline $\begin{array}{l}\text { Applicant } \\
\text { Name: }\end{array}$ & & $\begin{array}{l}\text { Application } \\
\text { Number: }\end{array}$ & $\begin{array}{l}\text { Project } \\
\text { Name: DWI } 1630\end{array}$ \\
\hline State: $\frac{T N}{\text { Date: }}$ & County: KNoX & $\begin{array}{l}\text { Legal Description: } \\
=\text { CAP }-4\end{array}$ & $\begin{array}{l}\text { Township: }=\text { Range } \\
\text { Section: }\end{array}$ \\
\hline
\end{tabular}

Vegetation [11st the threc dominant species in each vegetation layer (5 if only 1 or 2 layers)]. Indicate spectes with observed morphological or known physlological adaptations with an asterisk.

Species $\quad \underline{\begin{array}{c}\text { Indicator } \\ \text { Status }\end{array}}$ Species $\quad \underline{\begin{array}{c}\text { Indicator } \\ \text { Status }\end{array}}$

\section{Trees}

1.

2. MOME

3.

Saplings/shrubs

4. Cornus amomum

5.

6.

$z$ of species that are OBL, FACW, and/or

Hydrophytic vegetation: Yes $X$ No
Herbs

7. Bidens polylepis FACW

8. Carexvulpinodea OBL

9. Carex frankil $O B L$

Woody vines

10.

11.

12.

So11

Series and phase: Clayfill soil on hydric soils list? Yes_; No $X$;

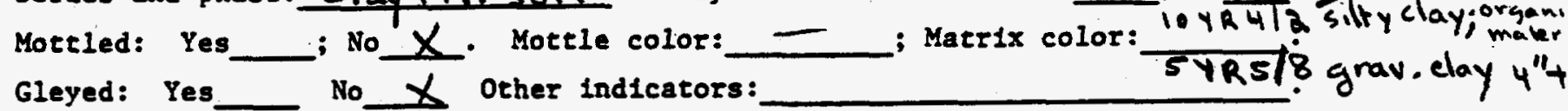

Gleyed: Yes__ No $X$ Other Indicators:
Hydric so1ls: Yes __ No $X$; Basis: Absence of hydric indreators; Fill soil

- Basis: OBL and FACW dominance

Hydrology

Inundated: Yes ; No $X$. Depth of standing water:

$22 " 3^{\prime \prime}$

Saturated soils: Yes $X$; No - Depth to saturated so1l: At surface.

Other Indicators:

Wetland hydrology: Yes $X$; No

- Bas1s: Ponded water; surfacesaturation

Atyplcal situation: Yes $X$; No

Normal Circumstances? Yes No $x$.

Wetland Determination: Wetland K__ Nonwetland

Comments: Man-induced Atypical Situation; Isolated depression in clay landfill Approw size: $113 \mathrm{~m}^{2}$ (0.0 $\left.11 \mathrm{ha}\right)$ - Determined by: B. ROSENSTEEL

See Data Form 3

JAYCOR ENVIRONMENTAL 
Applicant

Name :

Location: South Knoxville,

A. VEGETATION:

1. Type of Alteration: Oriainal valley wr: used as a landfill/saluage storage site . Later was capped with claysol.

2. Effect on Vegetation: original vegetition has been covered with landfill

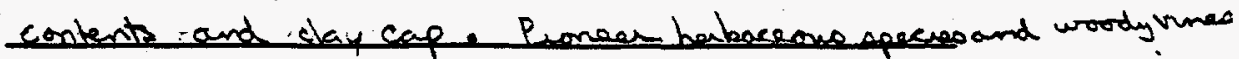

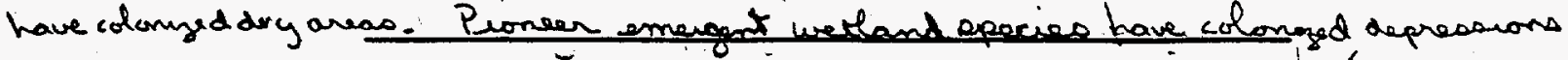

3. Previous Vegetation: No knoul docomentetion of prevans vegetatien. (Attach documentation)

4. Hydrophyt1c Vegetat1on? Yes No

B. SOILS:

1. Type of Alteration: Original sol covered by teno of fort of landf.le contents and fold 00

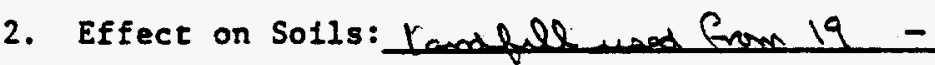
Cappod in 198

3. Previous So1ls:

(Attach documentation)

4. Hydric Solls? Yes No $x$

C. HYDROLOGY:

1. Type of Alteration: Depressions in clay cap holds precipitatim cus run off

2. Effect on Hydrology: Minimal drainage through low permeability clay. No sarface outlets ford the depresions

3. Previous Hydrology: Unknown

(Attach documentation)

4. Wetland Hydrology? Yes No Characterized By: B. Rosensteel 


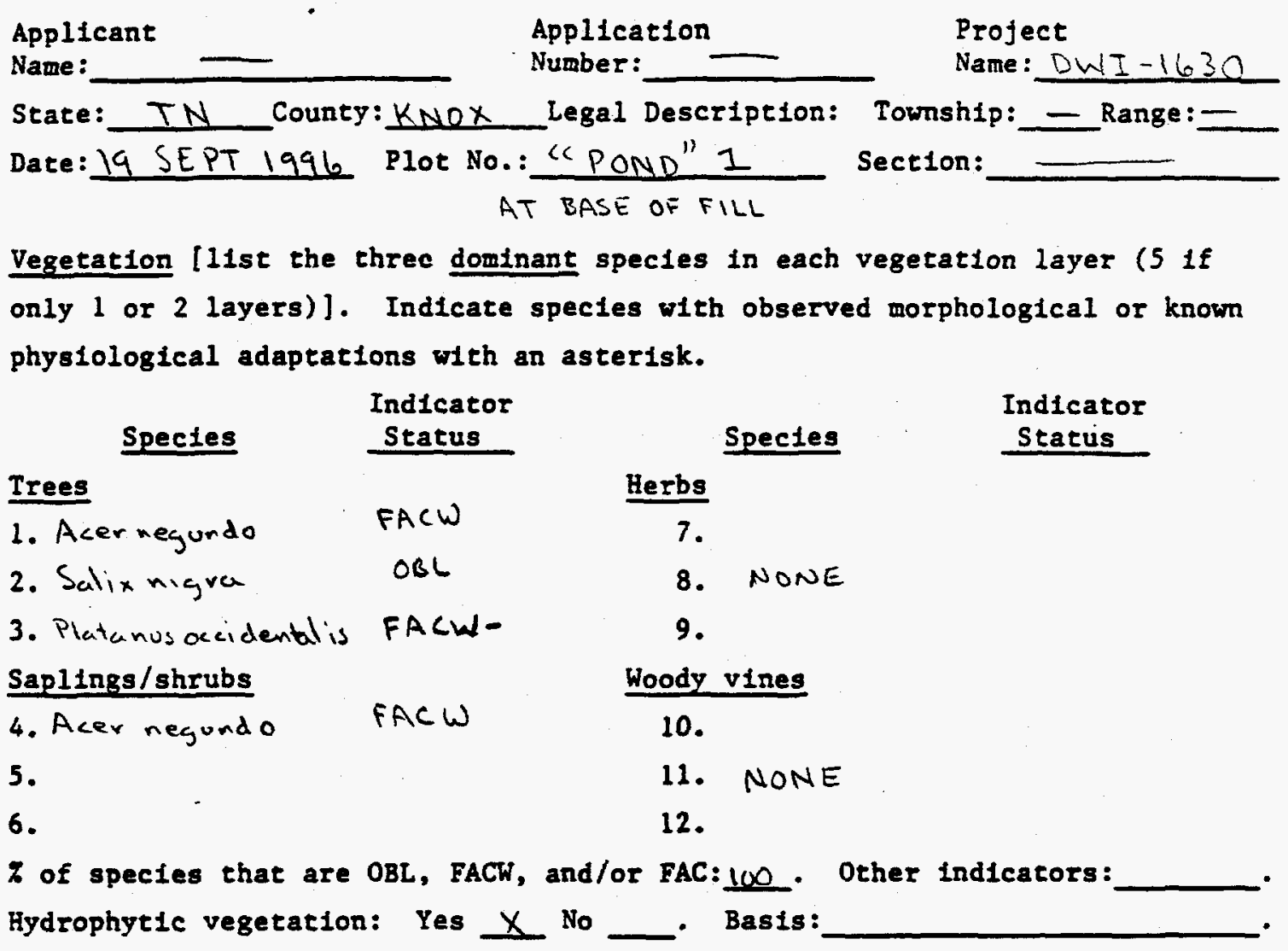

So11

Series and phase:

Mottled: Yes $X$; No

On hydric solls 11st? Yes ; No

Gleyed: Yes No ? 7.5 YR Sh ; Matrix color: - Motele color: SYRपाप Other Indicators: $\begin{aligned} & \text { SYR4/4 } \\ & \text { Museretoms }\end{aligned}$

Hydric soils: Yes $X$ No ; Basis: Matrix color and mottles

\section{Hydrology}

Inundated: Yes___ No $X$ _. Depth of standing water:

underlying Saturated so11s: Yes__; No $X$. Depth to saturated so11: Surface was wet; clay was no Other Indicators: Gr und devoid of herbaceous vegetation; Ponded water observed Dec - Mare Wetland hydrology: Yes $X$; No__. Basis: Absence of groundeover; Observed ponding Atypical situation: Yes__; No $X$. Normal Circumstances? Yes $X$ No it has not been determinid if ponding occurred in growing season Wetland Determination: Wetland ; Nonwetland

Comments: Area was disturbed in the past-(was used as a site reterition pond) but has not been recently cleared or disturbed. Clay layer perches precipitation but restricts groundweter
Determined by: B. BOSENSTEEL 


\begin{tabular}{|c|c|c|c|}
\hline $\begin{array}{l}\text { Applicant } \\
\text { Name: }\end{array}$ & & $\begin{array}{l}\text { Application } \\
\text { Number: }\end{array}$ & $\begin{array}{l}\text { Profect } \\
\text { Name:DWI - } 1630\end{array}$ \\
\hline 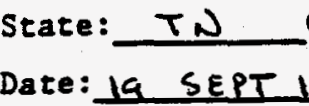 & $\begin{array}{l}\text { County: KNOX } \\
1996 \text { Plot No }\end{array}$ & $\begin{array}{l}\text { Legal Description: } \\
: \text { PoND" } 2\end{array}$ & $\begin{array}{l}\text { Township: }- \text { Range: } \\
\text { Section: }\end{array}$ \\
\hline
\end{tabular}

Vegetation [1ist the three dominant species in each vegetation layer (5 if only 1 or 2 layerg)]. Indicate species with observed morphological or known physlologtcal adaptations with an asterisk.

Species
$\begin{aligned} & \text { Indicator } \\ & \text { Stacus }\end{aligned}$

Hydrophyt1c vegetation: Yes $X$ No _. Basis: UBL, FACW Dominance

So11

Series and phase:

On hydric solls list? Yes ; No

Mottled: Yes $X$; No__. Mottle color: 7.5 Y $R$ 5/6; Matrix color: 10 YR $5 / 6$. Silty day loam Gleyed: Yes__ No $X$ Other Indicators:

Hydric solls: Yes___ No____ Basis:

Hydrology

Inundated: Yes____ No $X$. Depth of standing water: $5^{\prime \prime}$

Saturated so1ls: Yes $X$; No ___. Depth to saturated soll: Surface.

Other 1ndicators: Patches of bave substrats indicate ponding _.

Wetland hydrology: Yes $X$; No___ Basis:

Atypical situation: Yes___ No $X$.

Normal C1rcumstances? Yes $X$ No

Wetland Determination: Wetland _ X ; Nonwetland

Comments: Groundwater diacharge wetland. Bermat site boundary probubly aids in detention of runoff, also

Determined by: B. ROSENSTEEL 


\section{DISTRIBUTION}

1. L. V. Asplund

2-3. J. A. Mortimore

4. P. T. Owen

5. L. B. Raulston

6. P. A. Schrandt

7. Central Research Library

8. File-EMEF DMC-RC

9-11. T. Goode, Jacobs Engineering Group Inc., 125 Broadway Avenue, Oak Ridge, Tennessee 37830

12. B. A. Rosensteel, JAYCOR Environmental, Oak Ridge, Tennessee, 37830 
JAYCOR Environmental

contributed to the preparation of this document and should not be considered an eligible contractor for its review. 